\title{
Is Bankruptcy Risk a Systematic Risk? Evidence from Pakistan Stock Exchange
}

\author{
Imran Umer Chhapra ${ }^{1 *}$, Iffat Zehra ${ }^{2}$, Muhammad Kashif ${ }^{3}$, Raja Rehan ${ }^{4}$ \\ *Corresponding author
}

\begin{abstract}
This study empirically investigates the relationship between default risk and crosssection of stock returns in the Pakistan Stock Exchange (PSX). Stock price data from all listed and delisted companies use to calculate monthly returns from 2001-2016. Ohlson's O-score is employed to measure exposure of firm to systematic deviation within bankruptcy risk. Besides, asset-pricing models like the Capital Asset Pricing Model (CAPM) and Fama French (FF) models are employed. Portfolios are sorted in deciles by default probability. This result finds that stocks of firms significantly exposed to not diversified Default Risk yield higher returns. Besides that, the FF models explain cross-sectional stock returns since factors incorporate information on financial distress and default. After that, the book-to-market equity factor is not significant in elucidating returns of distressed firms because of market inefficiency. Results have practical implications for portfolio managers and investors of an emerging economy in developing diversified portfolios during periods of uncertainty and market volatility.
\end{abstract}

Keywords: distress risk, systematic risk, bankruptcy, asset pricing, Pakistan stock exchange

JEL Classifications: G12, G15, G33

\begin{abstract}
Abstrak. Studi ini menyelidiki secara empiris hubungan antara risiko default dan crosssection pengembalian saham di pasar modal Pakistan (PSX). Data harga saham dari semua perusahaan yang terdaftar dan yang delisting digunakan untuk menghitung pengembalian bulanan dari 2001-2016. O-score Oblson digunakan untuk mengukur paparan perusahaan terhadap penyimpangan sistematis dalam risiko kebangkrutan. Selain itu, model penetapan harga aset seperti model CAPM dan model Fama-French (FF) digunakan. Portofolio diurutkan dalam desil berdasarkan probabilitas default. Hasil ini menemukan bahwa saham perusahaan yang terpapar secara signifikan terhadap risiko gagal bayar yang tidak terdiversifikasi menghasilkan pengembalian yang lebih tinggi. Selain itu, model FF menjelaskan pengembalian saham cross-sectional karena faktor memasukkan informasi tentang kesulitan keuangan dan default. Setelah itu, faktor ekuitas nilai buku terhadap pasar tidak signifikan dalam menjelaskan pengembalian perusahaan tertekan karena ketidakefisienan pasar. Hasil memiliki implikasi praktis untuk manajer portofolio dan investor dari ekonomi baru dalam mengembangkan portofolio yang terdiversifikasi selama periode ketidakpastian dan volatilitas pasar.
\end{abstract}

Kata Kunci: risiko distress, risiko sistimatik, kebangkrutan, penilaian aset, pasar modal Pakistan

\section{How to Cite:}

Chhapra, I. U., Zehra, I., Kashif, M., \& Rehan, R. (2020). Is Bankruptcy Risk a Systematic Risk? Evidence from Pakistan Stock Exchange. Etikonomi: Jurnal Ekonomi, 19(1), 51 - 62. https://doi.org/10.15408/etk.v19i1.11248. 


\section{Introduction}

Risks can categorize into two types; systematic, which is not diverse and unsystematic, which can be diversified. An outsized return compensated as premium for systematic component (high betas) is anticipated under rational asset pricing models. Among such risks is the risk of default that can result in enormous losses for an equity investor? Conversely, when tested empirically using the company's financial variables, investments in distressed securities exhibit divergence of realized returns from expected returns, yielding low returns, which gives rise to the distress risk effect (Anginer \& Yıldızhan, 2018).

Distress risk puzzle characterizes by poor stock performance of financially distressed firms concerning negative excess returns. The concept has pronounced in asset pricing literature by Chan \& Chen (1991), and Fama \& French (1992, 1993, 1996). Specifically, in times of higher market volatility, distressed stocks yield low, which implies their vulnerability to increases in market risk (Campbell et al., 2008).

The argument on the anomalous return pattern of distressed equities is unsettled. While, others state that it is a bias and present prima facie indication against risk models stating beta's ability to undervalue distress risk (Campbell et al., 2008; Griffin \& Lemmon, 2002; Dichev, 1998; Ferguson \& Shockley, 2003). Others refute it as a puzzle and establish a positive association of distress risk with expected returns (Boualam et al., 2017; Chava \& Purnanandam, 2010; Vassalou \& Xing, 2004). Then again, there are empirical considerations that acknowledge the negative association of stock returns with credit risk but do not consider this as an anomaly (Garlappi \& Yan, 2011; Harvey \& Siddique, 2000) advocating that bankruptcy process itself results in low asset betas for distressed firms.

Studies are questioning the presence of distress anomaly quote reasons behind it. It occurs due to unforeseen events during the sample period of review (Campbell et al., 2008). Besides that, it is a historic US market specific phenomena only (Chava \& Purnanandam, 2010). Also, the prices of distressed stocks miscalculate because investors are unable to estimate failure risk (Eisdorfer et al., 2015). This phenomenon is due to the empirical limitation of the simple linear model in capturing excess returns that lead to partialities in estimated factor loadings of distressed stocks portfolio (Boualam et al., 2017). A study conducted by Ferguson \& Shockley (2003) validates that stock of distressed companies gives lower returns as compared to non-distressed firms, quoting market under-reaction hypothesis as a plausible reason for such behavior.

Li et al. (2017) had tests shareholder advantage assumptions to delve into reasons for the existence of distress anomaly. Findings confirm that future expected stock returns are negatively associated with a firm's position of financial distress. Moreover, during the period of observations, violation of shareholder advantage hypothesis observe, as equity risk remains insensitive to company cash flow. Researchers explain that when paralleled with companies having less risk of default, companies with a higher risk of default are likely able in overinvesting, generating low profits, hence using up all cash flows. Within subsamples, it observes that distress risk influence over equity returns was more substantial and more 
visible in companies with the lower opportunity of growth, firms having no credit rating, and companies whereby CEOs have equity holdings.

On the other hand, Garlappi et al. (2006) uses Moody-KMV's as a measure of default probability and emphasizes on shareholder's advantage and control within distressed firms. If shareholders have less or no bargaining power in a firm, equity returns will tend to increase with increasing default probability, and vice versa. Moreover, specific evidence supporting irrational return behavior on distressed stocks attributes it to mispricing that is market's failure in pricing distress risk accordingly (Dichev, 1998; Campbell et al., 2008). A negative risk premium sees if the market underreacts to bankruptcy risk that will cause the mispricing of stock prices. In case of underreaction, previous year returns (momentum) for stock prices will be low, and this pattern of low returns expects to continue in the future, which leads to negative risk premium (Agarwal \& Taffler, 2008). On the other hand, a positive premium would mean that investors have overreacted to news of failure of such firms and distress risk is associated with factors like size and book-to-market. However, it is not only the default risk which built into default spread but also a systematic risk, hence making default spread a poor predictor of returns for stocks carrying default risk (Vassalou $\&$ Xing, 2004).

Several studies on capital structure, with the earliest one proposed by Modigliani and Miller $(1958,1963)$ explain variability in stock returns through leverage. The theoretical model in George \& Hwang's (2010) research connects default risk with leverage and elucidates that companies that tend to take excessive leverage while making capital structure decisions increase their probability of default. Low leveraged companies are more exposed to not diversify risk due to which expected future return on stocks of such companies should be greater than those of high leverage companies (George \& Hwang, 2010). For medium to high-levered deciles, the leverage risk factor was empirically observed, having a strong relationship with equity returns (Artikis \& Nifora, 2011). Schneider et al. (2016) define the distress puzzle as a negative association of distress risk with a cross-section of equity returns. Leverage is using in the model as the primary indicator of bankruptcy that compares returns on leveraged portfolios, and contrasting results show that buying stocks of companies with high leverage and selling stocks of companies with low leverage produces negative returns, so much so that when accounted for return distribution, betas approach towards a value of zero. Market mispricing often quotes the reason behind such anomalous behavior.

Leary \& Roberts (2005) also attempts to associate distress risk with leverage. Their research based on the assumption that in order to evade the high cost of distress, firms opt for less leverage. During times of financial distress, such firms exhibit lower ROA (Return on Assets) when compared to high leverage companies. Findings indicate a more significant equity return premium in case of less leveraged companies when in distress. Hence, both earning performance, in terms of return on average assets as well as continuous exposure to not diversify risk, for low leverage firms appears to be impaired. Consistent with these results were findings from a study by Kayhan \& Titman (2007). During financial distress, companies having a high level of leverage suffer less as compared to firms with a low level of leverage who bear more. Besides, equity returns are also different for low and high leveraged 
firms as the difference in capital structure indicates variances in exposures to the financial distress cost. Capital structure decisions are hence made by mangers to evade such costs.

The famed Fama \& French (1992) asset pricing study on the three-factor model initially attributed value premium on stocks to financial distress risk, which then led to a series of studies on the behavior of distressed stocks. Their study included beta, size (small minus big$\mathrm{SMB}$ ), and value premium (high minus low-HML) as three factors. Financially distressed firms characterize with high betas and high factor loadings for value premium (HML) and size (SMB) (Fama \& French, 1992, 1996). The initial structural model on default by Merton (1974) suggests that not only return on financial securities (such as equities and bonds) but also the probability of default is driven by aggregate risk factors. Hence, when we control for risk factors as proposed by Fama \& French (1993), there should not be any different for returns of portfolios for companies having a higher risk of default and return on portfolios comprising lower risk of default. Concerning the factor model postulated by Fama \& French (1996), researchers Vassalou \& Xing (2004) argue that SMB and HML as proxies of default risk contain information on default, but these factors are unable to explain equity returns. Their study uses Merton's option pricing model to evaluate the impact of default risk on stock returns and concludes that small-sized companies with high BM and high default risk generate higher returns when compared with low default risk firms. In the absence of these firm characteristics, the study concludes that high default risk firms do not earn a higher return.

On a different tangent, Chen et al. (2010) claim to explain many market anomalies through their study that the Fama-French model could not. Amongst such is the distress puzzle characterized by negative relation of average returns with financial distress. The researchers propose a different three-factor model that includes market factor, a low-minushigh investment factor, and a high-minus-low ROA factor. They employ ROA to expected return relation to account for anomaly whereby findings indicate that financially distressed firms have a lower expected return on assets (ROA), which makes them less profitable, and hence they generate lower returns. Kapadia (2011) renews the idea through research findings that distress risk is explained best in terms of size and value premiums. Findings indicate that value and size factors under Fama $\&$ French model can use to predict future failure rates. The study makes use of business failure data for both private and public limited companies, which use to predict future failure. Lower returns are witnessed for small stocks, whereas during times of market expectation of high firm failure, value stocks yield lesser returns as compared to growth stocks.

Different studies have employed different proxies to estimate the probability of bankruptcy. Campbell et al. (2008) suggest that financial distress risk capture by momentum as previous year returns can use to predict future bankruptcy. They present a self-developed measure for financial distress by using bankruptcy filing details and financially driven default ratings provided by credit rating agencies on companies. Equity market variables included data on monthly excess stock return, volatility in daily stock returns, and market capitalization. Accounting data used were the ratio of net income to the market value of assets, total leverage to the market value of total assets, cash holdings, and market to book ratio. Declining sales 
and earnings, coupled with high leverage, are some characteristics linked with distress risk (Griffin \& Lemmon, 2002). Stock volatility, operating assets volatility, and cash flow position are factors used to measure distress risk (Gormley \& Matsa, 2016). More popular and widely used measures for predicting financial distress are Altman Z-score (Altman, 1968) and Ohlson 0 -score (Ohlson, 1980) that make use of accounting variables. Many studies have used accounting ratios based z-score model as a measure for default risk (Dichev, 1998; Griffin \& Lemmon, 2002; Agarwal \& Taffler, 2008). Anginer \& Yildızhan (2018) examine default risk pricing within the cross-section of equity returns. They use corporate bond credit spread as a new proxy first to calculate the risk premium of distressed firms, as it believes that it does not diversify the portion of default risk that should adjust in prices. Findings indicate that stocks of companies having greater systematic risk of default earn higher expected returns.

Gao et al. (2018) used a cross-section of equity returns for 44,000 distressed firms, from 38 countries to examine distress anomaly. They employ Moody-KMV's EDF (Expected Default Frequency) estimates as a proxy for default risk. Findings indicate that robust and negative relation of equity returns with credit risk that anomaly characterizes due to mispricing and financially distressed stocks close to bankruptcy are momentarily overpriced. On the other hand, research conducted by Schneider, et.al (2016) confirmed on the presence of distress anomaly as they observed negative returns in buying high leveraged stocks and selling stocks of low leverage firms within their value weighted portfolios. Furthermore, it notes that when compared to low leverage stocks, the performance of stocks for companies with high leverage deteriorates when standard factors were employed to correct for risk, and alphas for the four-factor model were significantly negative. Comparatively, the results were similar for equal-weighted portfolios.

While studying potential return drivers, Eisdorfer et al. (2015) used cross-country data to report that distress risk effect is more discernible in developed markets as compared to emerging ones. The study cites robust takeover legislation of distressed companies, weak arbitrage barriers, and greater information transparency as some reasons behind a more robust anomaly. It is challenging to take arbitrage positions in stocks of distressed companies (Eisdorfer et al., 2015), making them riskier. Within the US market, distress anomaly observes to be higher in small-cap companies (Campbell et al. 2008). Within developed markets other than the US, similar results observe. Moreover, Lai et al. (2017) observe that financial distress price within returns, and it is not an anomaly. They suggest Cahart's four-factor financial distress model explains equity returns within Asian markets.

Although prior research on evaluating distress risk in equity returns of PSX stocks is available, our study is distinct in the following ways. Firstly, we propose O-score along with three different factor models to estimate the distress risk premium. Also, the study makes use of stock return data from both listed and delisted companies to assess the historical return pattern of distressed stocks and substantiate if they underperform. This approach is the main novelty since previous studies have used only data from listed companies to verify the same. We create portfolios using a large sample of 901 companies from 2001 to 2016 to analyze their properties, avoiding survivorship bias, which to the best of authors' knowledge, has not done before. Another difference from previous research on Pakistan is that rather than 
choosing selective stocks from specific sectors, all sectors consider making it first of its kind research paper for an emerging country like Pakistan.

\section{Methods}

Distress risk anomaly has tested using Ohlson (1980) O-Score, which is estimated through nine factors linear combination of coefficient weighted accounting ratios. O-score is calculating for each firm in our sample for period t-1. O-Score equation is:

$T=-1.32-0.407$ SIZE +6.03 TLTA -1.43 WCTA + 0.076CLCA - 1.72OENEG - 2.37NITA

\section{-1.83 FUTL + 0.285INTWO -0.521 CHIN}

Where SIZE is the log of total assets divided by log of GNP price level index; TLTA is total liabilities divided by total assets; WCTA is working capital (current assets minus current liabilities) divided by total assets; CLCA is current liabilities divided current assets; OENEG is a dummy variable. Assign 1, if total liability > total assets otherwise assign 0, NITA is net income divided by total assets; FUTL is the funds from operations (pretax income) divided by total liabilities; INTWO is a dummy variable. Assign 1, if a net loss for the last two years, otherwise assign 0 ; and CHIN is changes in net income which is calculating as $\left(\mathrm{NI}_{\mathrm{t}}-\mathrm{NI}_{\mathrm{t}-1}\right)$ divided by $\left(\left|\mathrm{NI}_{\mathrm{t}}\right|+\left|\mathrm{NI}_{\mathrm{t}-1}\right|\right)$. Data type total assets (wc02999), GNP price level index, total liabilities (wc03351), total current liabilities (wc03101), earnings after interest and taxes and earnings before taxes (wc18191) from Thomson DataStream are using for estimation of O-Score. After calculating O-scores, decile portfolios are constructed at the end of June of every year $(t)$ using PSX breakpoints. Then, returns of monthly value weighted decile portfolios are estimating from July of year $(t)$ to June of year $(t+1)$ and portfolios are rebalanced in June of year $(t+1)$.

Single sorting or post ranking method has been employed for portfolio construction. Monthly stock returns $\left(\mathrm{r}_{\mathrm{r}}\right)$ have sorted in an ascending series, on the basis of $\mathrm{O}$-scores of each individual stock $\left(\mathrm{O}-\mathrm{Score}_{\mathrm{t}-1}\right)$. To calculate portfolio-sorted returns at time $\mathrm{t}$, Market Value is sorted monthly at lags $\left(\right.$ time $_{\mathrm{t}-1}$ ). Sorted data is arrayed in symmetric and increasing order into deciles, ranging from P1-P10, starting from low to high distressed firms. To ensure distressed based portfolio's robustness, equally weighted (EW) and value weighted (VW) returns are generated in excess of the risk-free rate (6 months T-bills). Furthermore, Jensen's alpha and Fama French's alphas are estimated and reported to measure the risk-adjusted performance of equally weighted and value weighted portfolios (P1 to P10) based on distress risk. The following formula is using to estimate Jensen's alpha:

$$
K_{i, t}-K_{r f, t}=\alpha_{i}+\beta_{i, m}\left(K_{m, t}-K_{r f, t}\right)+\varepsilon_{i, t}
$$

Where, $K_{i, t}$ is the return of portfolio (i) in month $(t), K_{r f, t}$ is the risk free rate at month $(t)$, and $\left(K_{m, t}-K_{r f, t}\right)$ is the excess return of market portfolio in month $(t)$. For Fama French alpha, the Fama French (1993) three factor model and Fama French (2015) five factor model are used respectively:

$$
\begin{aligned}
& K_{i, t}-K_{r f, t}=\alpha_{i}+\beta_{i, m}\left(K_{m, t}-K_{r f, t}\right)+\beta_{i, S M B}(S M B)_{t}+\beta_{H M L}(H M L)_{t}+\varepsilon_{i, t} \\
& K_{i, t}-K_{r f, t}=\alpha_{i}+\beta_{i, m}\left(K_{m, t}-K_{r f, t}\right)+\beta_{i, S M B}(S M B)_{t}+\beta_{H M L}(H M L)_{t}+\beta_{R M W}(R M W)_{t}+\beta_{C M A}(\mathrm{CMA})_{t}+\varepsilon \mathrm{i},
\end{aligned}
$$


Where, $S M B_{t}$ is the size risk factor in month $(t), H M L_{t}$ is the value risk factor in month $(t), R M W_{t}$ is the operating profitability risk factor in month ( $\left.t\right)$ and $C M A_{t}$ is the investment risk factor in month $(t)$. The joint significance of the decile portfolio alphas is tested by using systems of equations explain the importance of using system of equation that helps to overcome the issue of measurement error in variables and the problems of heteroscedasticity and serial correlation can also be corrected if alphas are estimated by using generalized methods of moments (GMM). Moreover, the Wald test is applied to verify whether the null hypothesis $\left(H_{o}: \alpha \mathrm{i}=0[\right.$ for $\left.i=1,2,3 \ldots . .10]\right)$ of zero alpha estimates is correct, which explains the significance of return differential among the decile portfolios.

\section{Result and Discussion}

First, preliminary descriptive statistics of decile portfolios of distressed companies present in Table 1, followed by a discussion on risk-adjusted Equally Weighted (EW) and Value Weighted (VW) returns generated from the time-series asset pricing tests. We developed annualized portfolios for both EW and VW monthly returns, on an annualized basis. Decile portfolios ranging from P1 to P10 are forming, representing the lowest and highest distressed companies, respectively. The level of spread is the difference between P10-P1.

Table 1. Characteristics of Decile Portfolios based on Distress Risk

\begin{tabular}{lcccccccccccc}
\hline & P1 & P2 & P3 & P4 & P5 & P6 & P7 & P8 & P9 & P10 & P10-P1 t-test \\
\hline EW Excess Returns (\% p.a) & 17.9 & 25.45 & 21.14 & 29.1 & 31.1 & 26.4 & 34.1 & 34.3 & 33.2 & 43.5 & 25.61 & 2.80 \\
VW Excess Returns (\% p.a) & 14.6 & 23.80 & 20.19 & 23.3 & 22.3 & 21.9 & 27.2 & 30.9 & 24.2 & 33.2 & 18.6 & 1.74 \\
MV (Rs. tn) & 1.2 & 0.38 & 0.20 & 0.15 & 0.09 & 0.07 & 0.04 & 0.02 & 0.01 & 0.01 & -1.21 & -20.6 \\
CAPM $\beta$ & 1.07 & 0.90 & 0.79 & 0.89 & 0.57 & 0.83 & 0.83 & 0.86 & 0.51 & 0.80 & -0.27 & -1.99 \\
\hline
\end{tabular}

Table 1 shows the descriptive statistics of decile portfolios based on distress risk from January 2001 to December 2016. The results of the excess return of value-weighted and equally weighted portfolio show that lowest size portfolio (P1) is having lowest distress risk and generating lower returns (EW returns $=17.90 \%$ p.a. and VW returns $=14.57 \%$ p.a. $)$ in comparison to other equally weighted and value-weighted (P2 to P10) portfolios. On the side P10 is the highest distress risk portfolio generating higher returns (EW returns $=25.61 \%$ p.a. and VW returns $=18.59 \%$ p.a.) in comparison to other portfolios. The return spread and t-test values (in parenthesis) between two extreme portfolios (P10-P1) for equally weighted and value-weighted portfolios are 25.61\% (2.80) and 18.59\% (1.74) indicating that both portfolios returns are statistically significant and there is a difference in means between the characteristics of P10 and P1. Hence, our results are in line with the value theory discussed in the previous section.

The risk-adjusted performance of returns is using to confirm on the distress risk anomaly. For estimation, GMM is employing whereas CAPM's Jensen Alpha and 3 and 5 factor Fama-French model is using for analysis. For value-weighted (VW) distressed portfolios, 
Jensen alpha for P1 (low distress firms) was highly significant. Alpha for P5 ( $\mathrm{t}=1.51)$ and P9 $(\mathrm{t}=1.52)$ was significant at 10\%. Likewise, the alpha results, except for P1 and P10, under the three-factor Fama French model failed to explain the significance. P1 and P10 were significant at $5 \%(\mathrm{t}=-2.14)$ and $10 \%(\mathrm{t}=1.51)$, respectively. Under both, the models, beta values for low distress companies were less than the beta estimate of high distress firms. Comparatively, higher returns are expecting with firms having a greater probability of default, indicating the absence of distress anomaly. The results are aligning with the findings of Mselmi et al. (2019) that states that distress risk factor does not yield abnormal returns.

Table 2 presents the risk-adjusted performance of the decile value-weighted distress risk portfolios. Data includes all shares listed on PSX from January 2001 till December 2016. Data sort in ascending order at month ( $\mathrm{t}$ ) to estimate distress risk values by using 36 months rolling window of observations and all portfolios rebalance monthly. The decile portfolio P1 represents stocks with the lowest estimated distress risk, and the decile portfolio P10 contains stocks with the highest estimated distress risk, and P10-P1 is the spread between highest distress risk portfolio (P10) and lowest distress risk portfolio (P1). CAPM alpha, FF3 alpha, and FF5 alpha present the annualized estimation of alphas derived from CAPM, FamaFrench three-factor, and Fama-French five-factor, respectively. Finally, the Wald test reports chi-square statistics referring to the null hypothesis that all ten alphas of decile portfolios are jointly equal to zero, and their p-values are in parenthesis below the statistic.

Table 3 presents the risk-adjusted performance of the decile value-weighted distress risk portfolios. Data includes all shares listed on PSX from January 2001 till December 2016. Data sort in ascending order at month ( $\mathrm{t}$ ) to estimate distress risk values by using 36 months rolling window of observations and all portfolios rebalance monthly. The decile portfolio P1 represents stocks with the lowest estimated distress risk, and the decile portfolio P10 contains stocks with the highest estimated distress risk, and P10-P1 is the spread between highest distress risk portfolio (P10) and lowest distress risk portfolio (P1). CAPM alpha, FF3 alpha, and FF5 alpha present the annualized estimation of alphas derived from CAPM, FamaFrench three-factor, and Fama-French five-factor, respectively. Finally, the Wald test reports chi-square statistics referring to the null hypothesis that all ten alphas of decile portfolios are jointly equal to zero, and their p-values are in parenthesis below the statistic.

Table 3 presents CAPM and FF three-factor model results with equal weight given to each variable. The result of the EW portfolio for P1-P10 deciles is significant under both CAPM and three-factor Fama-French model. CAPM Jensen Alpha value is low (negative) 9.35 for low distress companies, P1, and high (positive) 26.29 for P10, high distress firms. Besides, the partial difference is positive and statistically significant $(t=3.65)$. Similar results see for the Fama-French three-factor model where annualized returns calculated monthly is negative 7.73 for P1 and positive 31.25 for P10. The level of spread is statistically significant $(\mathrm{t}=3.26)$ at positive 38.98. Cross-sectional variation in returns is observed through Wald test values, as we move through deciles towards more financially distressed firms. This result supports the non-existence of distress anomaly in the Pakistan Stock Exchange (PSX), also observed through descriptive statistics mentioned above. 
Additionally, results are consistent with the findings of Idrees \& Qayyum (2018) for PSX selected stocks, and Griffin \& Lemmon (2002) and Campbel et al., (2008). The beta coefficient under both CAPM and FF three factors was reported low at negative 0.01 for P1 (low distress firms) parallel to P10 companies. It is evident from the results that loadings for P1 (low distress company) under CAPM and Fama- French Three-Factor Model for both equally and value-weighted portfolios is the lowest when compared to P10 (high distress company).

\section{Conclusion}

Appropriate pricing of financial distress risk in stock returns is a crucial issue within financial economics literature. This study aims to verify if financial distress plays a significant role in the pricing of Pakistani distressed and non-distressed portfolios throughout January 2001-December 2016. Our work is the first of its kind within Pakistan's context, as we consider not only listed but also delisted stock data to explain excess returns of financially distressed portfolios, by employing augmented models. The anomalies of the abnormal riskreturn tradeoff in high and low distress companies investigate by using Ohlson's O-score as a proxy for financial distress. We calculate returns and risks on decile portfolios sorted by probability of default. Consistent with rational asset pricing models, our results indicate that financially distressed stocks earn high returns and size, and B/M influences distress risk in stocks listed on Pakistan Stock Exchange. Ceteris paribus, adjusted returns are influenced by distress risk as a negative beta for low distressed firms was observed.

Conversely, firms with a higher risk of default will exhibit a higher beta, high B/M, and hence greater average returns. Small companies having a high risk of default tend to give higher stock returns as compared to large firms. Likewise, results from GMM substantiate specification of CAPM and Fama-French, three-factor models, in the case of PSX as they can explain cross-sectional variation in return of portfolios based on distress risk. Hence the asset pricing models confirm that default risk is systematic as size and $\mathrm{B} / \mathrm{M}$ encompasses pertinent price information, which is extraneous to default risk. Study findings bear practical implications for an investor, enabling him to comprehend the behavior of distressed stocks upon which he can make effective portfolio strategies and capitalize on different premiums, keeping his risk profile under consideration. Economic and psychological forces can be incorporated as part of future research to see if distress anomaly persists in the case of macroeconomic variable shocks. 


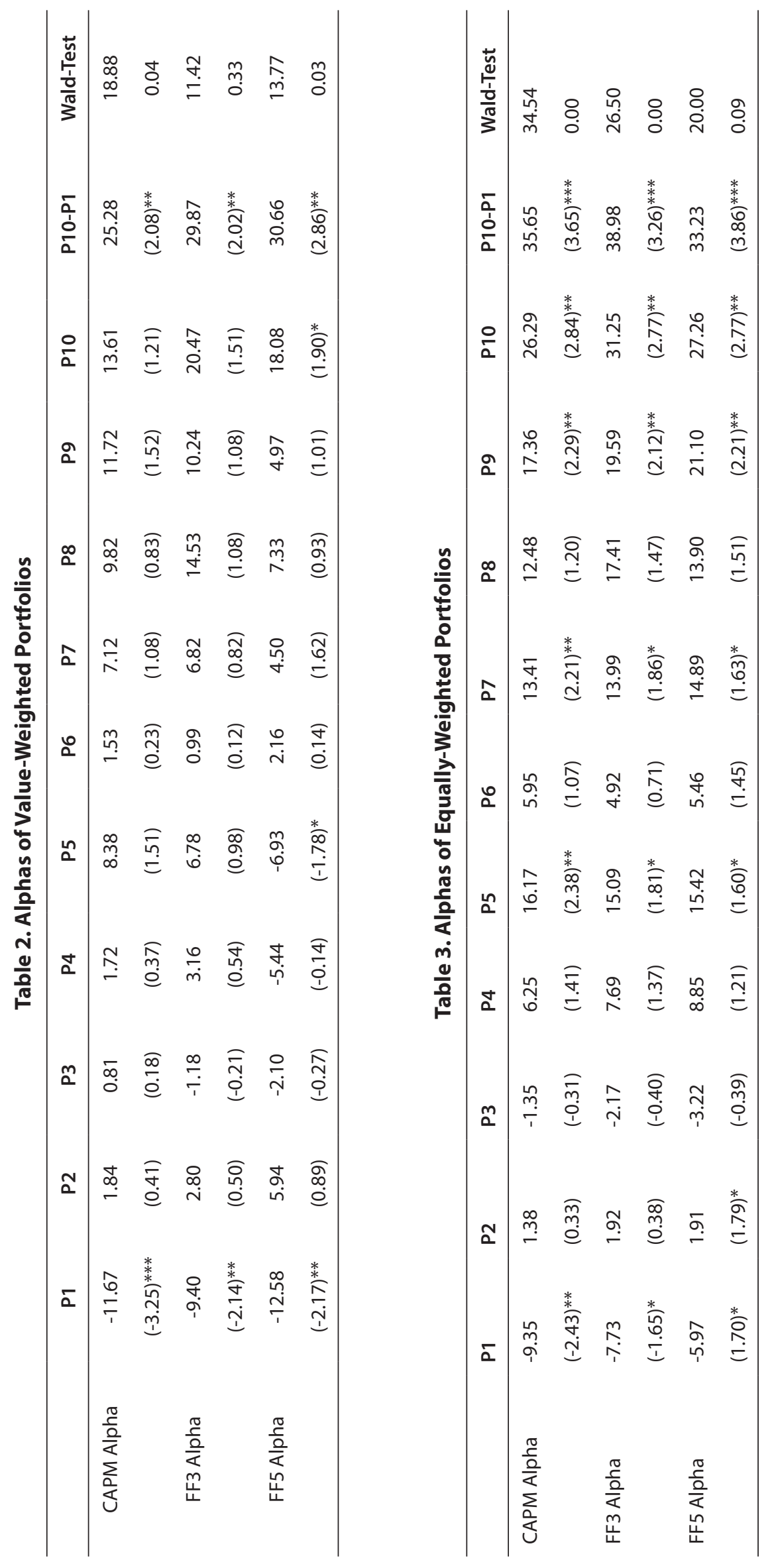




\section{References}

Agarwal, V., \& Taffler, R. (2008). Does Financial Distress Risk Drive the Momentum Anomaly? Financial Management, 37(3), 461-484. https://doi.org/10.1111/j.1755053X.2008.00021.x.

Altman, E, I. (1968). Financial Ratios, Discriminant Analysis and the Prediction of Corporate Bankruptcy. The Journal of Finance, 23(4), 589-609.

Anginer, D., \& Yildizhan, C. (2018). Is There a Distress Risk Anomaly? Pricing of Systematic Default Risk in the Cross Section of Equity Returns. Review of Finance, 22(2), 633-660

Artikis, P., \& Nifora, G. (2011). The Industry Effect on The Relationship Between Leverage and Returns. Eurasian Business Review, 1(2), 125-144. https://doi.org/10.14208/BF03353802.

Boualam, Y., Gomes, J. F., \& Ward, C. (2017). Understanding the Behavior of Distressed Stocks. Discussion paper University of North Carolina, University of Pennsylvania, and University of Minnesota.

Campbell, J. Y., Hilscher, J., \& Szilagyi, J. (2008). In Search of Distress Risk. The Journal of Finance, 63(6), 2899-2939.

Chan, K. C., \& Chen, N. F. (1991). Structural and Return Characteristics of Small and Large Firms. The Journal of Finance, 46(4), 1467-1484

Chava, S., \& Purnanandam, A. (2010) Is Default Risk Negatively Related to Stock Returns? The Review of Financial Studies, 23(6), 2523-2559.

Chen, L., Novy-Marx, R., \& Zhang, L. (2010). An Alternative Three-factor Model. Working Paper. University of Rochester.

Dichev, I. (1998). Is the Risk of Bankruptcy a Systematic Risk? The Journal of Finance, 53(3), $1131-1147$

Eisdorfer A., Goyal A., \& Zhdanov, A. (2015). Distress Anomaly and Shareholder Risk: International Evidence. Working Paper. University of Lausanne.

Fama, E. F., \& French, K. R. (1992). The Cross-Section of Expected Stock Returns. The Journal of Finance, 47(2), 427-466.

Fama, E. F., \& French, K. R. (1993). Common Risk Factors in The Returns on Stocks and Bonds. The Journal of Financial Economics, 33(1), 3-56.

Fama, E. F., \& French, K. R. (1996). Multifactor Explanations of Asset Pricing Anomalies. The Journal of Finance, 51(1), 55-84.

Ferguson, M. F., \& Shockley, R. L. (2003). Equilibrium “anomalies.” Journal of Finance, 58(6), 2549-2580.

Gao, P., Parsons, C. A., \& Shen, J. (2018). Global Relation between Financial Distress and Equity Returns. The Review of Financial Studies, 31(1), 239-277.

Garlappi, L., Shu, T., \& Yan, H. (2006). Default Risk, Shareholder Advantage, and Stock Returns. The Review of Financial Studies, 21(6), 2743-2778.

Garlappi, L., \& Yan, H. (2011). Financial Distress and The Cross-Section of Equity Returns. The Journal of Finance, 66(3), 789-822 
George, T. J., \& Hwang, C. (2010). A Resolution of The Distress Risk and Leverage Puzzles in The Cross Section of Stock Returns. Journal of Financial Economics, 96(1), 56-79. https://doi.org/ 10.1016/j.jfineco.2009.11.003.

Gormley T. A., \& Matsa D. A. (2016). Playing it Safe? Managerial Preferences, Risk, and Agency Conflicts. Journal of Financial Economics, 122(3), 431-455. https://doi. org/10.1016/j.jfineco. 2016.08.002.

Griffin, J. M, \& Lemmon, M. L. (2002). Book-to-Market Equity, Distress Risk, and Stock Returns. Journal of Finance, 57(5), 2317-2336

Harvey, C. R., \& Siddique, A. (2000). Conditional Skewness in Asset Pricing Tests. Journal of Finance, 55(3), 1263-1295. https://doi.org/10.1111/0022-1082.00247.

Idrees, S., \& Qayyum, A. (2018). The Impact of Financial Distress Risk on Equity Returns: A Case Study of Non-Financial Firms of Pakistan Stock Exchange. Journal of Economics Bibliography, 5(2), 49-59. https://doi.org/10.1453/jeb.v5i2.1623.

Lai, S., Li, H. C., Conover, J. A., Wu, F., \& Li, B. (2018). Stock Returns and Financial Distress Risk: Evidence from the Asian-Pacific Markets. Research in Finance, 33, 123 158. https://doi.org/10.1108/S0196-382120170000033007.

Li, K., Lockwood, J., Miao, H. (2017). Risk-Shifting, Equity Risk, and the Distress Risk Puzzle. Journal of Corporate Finance, 44, 275-288.

Leary, M., \& Roberts, M. (2005). Do Firms Rebalance Their Capital Structures? Journal of Finance, 60(6), 2575-2619. https://doi.org/10.1111/j.1540-6261.2005.00811.x.

Kapadia, N. (2011). Tracking Down Distress Risk. Journal of Financial Economics, 102(1), 167-182. https://doi.org/10.1016/j.jfineco.2011.05.004.

Kayhan, A., \& Titman, S. (2007). Firms' Histories and their Capital Structures. Journal of Financial Economics, 83(1), 1-32. https://doi.org/10.1016/j.jfineco.2005.10.007.

Merton, R. C. (1974). On the Pricing of Corporate Debt: The Risk Structure of Interest Rates. The Journal of Finance, 29(2), 449-470. https://doi.org/10.1111/j.1540-6261.1974. tb03058.x.

Mselmi, N., Hamza, T., Lahiani, A., \& Shahbaz, M. (2019). Pricing Corporate Financial Distress: Empirical Evidence from the French Stock Market. Journal of International Money and Finance, 96, 13-27. https://doi.org/10.1016/j.jimonfin.2019.04.008.

Ohlson, J. (1980). Financial Ratios and the Probabilistic Prediction of Bankruptcy. Journal of Accounting Research, 18 (1), 109-31.

Schneider, P., Wagner, C., \& Zechner, J. (2016). Low Risk Anomalies? CFS Working Paper Studies. Center for Financial Studies.

Vassalou, M., \& Xing, Y. (2004). Default Risk in Equity Returns. The Journal of Finance, 59(2), 831-868. 